\title{
YABANCILAŞMA VE ÜRETIM KARŞITI İŞ DAVRANIŞLARI: SAĞLIK KURUMLARINDA BİR ARAŞTIRMA
}

\author{
Burcu ÜZÜM ${ }^{1}$, Leyla ŞENOL ${ }^{2}$
}

\begin{abstract}
$\ddot{O} z$
Bu çalışmada, üretim karşıtı iş davranışları ve bu ilişkiyi etkileyen faktörlerin tespit edilmesi amaçlanmıştır. Araştırmanın amacı doğrultusunda nicel yöntem kurgulanmıştır. Yabancılaşma ve üretim karşıtı iş davranışları kavramlarının sağlık sektöründe birlikte pek araştırılmadığı görülmüştür. Araştırma evrenini, Kocaeli İli İzmit İlçesinde bulunan devlet hastaneleri çalışanları oluşturmaktadır. Çalışmaya kolayda örneklem yöntemine uygun gönüllü çalışanlar dahil edilmiştir. Örneklemi 185 çalışan oluşturmaktadır. Araştırmada üretim karşıtı iş davranışları ve yabancılaşma ölçekleri kullanılmıştır. Anket formunda cinsiyet, medeni durum, gelir, eğitim düzeyi olmak üzere dört adet kişisel bilgilere ilişkin sorular yer almaktadır. Araştırma sonucunda yabancılaşma ve üretim karşıtı iş davranışları arasında doğru yönlü ve pozitif bir ilişki bulunmuştur. Demografik değişkenlerden cinsiyetin üretim karşıtı iş davranışlarında farklılık yarattığı belirlenmiş, medeni durumun yabancılaşma ve üretim karşıtı iş davranışlarını etkilediği görülmüşsür.
\end{abstract}

Anahtar Kelimeler: Yabancılaşma, Üretim Karşıtı İş Davranışları, Sağlık Kurumları.

JEL Simıflaması: M1, M5, L2, I1

\section{ALIENATION AND COUNTERPRODUCTIVE BEHAVIOURS: A RESEARCH IN HEALTH INSTITUTIONS}

\begin{abstract}
In this study, it has been aimed at determining counterproductive behaviours and the factors affecting this relationship. In accordance with the study, a quantitative method has been developed. It has been realised that the concepts of alienation and counterproductive behaviours have not been researched together much in health sector. The population of the study is consisted of the employees of state hospitals which are in Izmit, Kocaeli. In addition, volunteers who are suitable for the convenience sampling method have been included in the study. The sampling is formed of 185 employees. In the study, alienation and counterproductive scales have been used. In the survey, there are personal information questions regarding four topics which are gender, marital status, income, and level of education. As a result of the study, it has been understood that there is a direct and positive relationship between alienation and counterproductive behaviours. Moreover, it has been discovered that due to demographic changes gender varies in counterproductive behaviours and that marital status has an influence on alienation and counterproductive behaviours.
\end{abstract}

Keywords: Alienation, Counterproductive Behaviours, Health Institutions.

JEL Classification: M1, M5, L2, I1

\footnotetext{
${ }^{1}$ Dr, Kocaeli Üniversitesi, Kocaeli MYO, Kocaeli, Turkiye, burcugokay@ gmail.com, ORCID:0000-00018675-8952

2 Dr, Kocaeli Üniversitesi, Ali Rıza Veziroğlu MYO, Kocaeli, Turkiye, senolleyla4@gmail.com, ORCID:0000-0002-5780-9690
} 


\section{Giriş}

Sosyal bir varlık olan insan; örgütlerin hedeflerine ulaşmasında, örgütsel becerilerin geliştirilmesinde bir örgütü diğer örgütlerden farklı kılan en önemli unsurdur. İnsanlar üreterek hem ekonomiye, hem örgütlerine katkıda bulunurlar. Çalışanlar bu katkılardan dolayı maddi ya da manevi olarak da örgütten karşılığını alma beklentisi içine girerler. Beklentileri karşılanmayan çalışanlar, yoğun iş temposu nedeniyle dış çevrelerine de ilgisiz kalmaktadır. Dış çevreye ilgisiz kalma, uzaklaşma, yabancılaşma olarak ifade edilmektedir. Bazen bu durum, çalışanların örgüt içinde iş-görevlerinin dışında rahatsız edici davranışlar göstererek performanslarını azaltmalarına ve örgütte istenmeyen bir ortam yaratmalarına neden olabilmektedir. Bireyin bir takım faktörlerden etkilenerek sosyal hayatın gerektirdiği kurallara uymaması ve hatta karşı taraftan gelen tepkiyi de göze alması bireyi motive edebilir; bu motivasyonda üretim dışı iş davranışlarına neden olabilmektedir. Bu çalışmada; her iki olumsuz davranışın birbiri ile olan ilişkisi sağlık sektörü çalışanlarının yabancılaşma ve üretim karşıtı iş davranışları eğilimlerinin ölçülmesi amaçlanmaktadır.

\section{Literatür Taraması}

\subsection{Yabancılaşma}

Yabancılaşma ilk defa Plotinos tarafindan "kendine yabancılaşma" olarak felsefi açıdan kullanılmıştır. (Aydoğan, 2015). Daha sonra yabancılaşma kavramını Hegel irdelemiştir (Osmanoğlu, 2016). Marx ise yabancılaşma kavramını iktisadi yönüyle ele almıştır.

Yabancılaşma en basit haliyle akıl hastası insanları tanımlamak amacıyla kullanılmıştır. Hegel ve Marx ise yabancılaşma kavramını akıl hastalığı yerine "kendinden hafifçe kopma" anlamında kullanmışlardır (Fromm, 1996). Yabancılaşma; kopma, ayrılık ve mutsuzluk olarak ifade edilirken, aynı zamanda bireyin çaresiz kalışını simgeler (Şimşek \& Ataş Akdemir, 2015). Günümüzde yabancılaşma; "birini başka bir şeyden ya da kişiden uzaklaştıran veya ona karşı yabancı duruma getiren eylem" olarak kullanılmaktadır (Aydoğan, 2015).

Yabancılaşma kendini sadece toplumsal yaşam içerisinde göstermez aynı zamanda iş yaşamında da karşılaşılan bir durumdur. Maddiyata verilen önem arttıkça, çalışanların iç dünyasında değersizleşme meydana gelir. Ancak çalışanın; iş süreçlerine kendisini yeterince dahil edememesi ve kendini gerçekleştirmedeki yetersizliği sonucu, yabancılaşma şeklinde tepki verdiği görülmektedir (Tutar, 2010). Yabancılaşma; güçsüzlük, anlamsızlık, kuralsızlık, soyutlanma ve öz yabancılaşma şeklindeki boyutlarla ele alınabilir (Tezcan, 1985). Bu boyutlar kısaca özetlenirse (Akyıldız \& Dulupçu, 2003; Şimşek vd., 2006; Mendoza \& Lara, 2007; Şimşek vd., 2012; Polat \& Yavaş, 2012; Salihoğlu, 2014; Yalçın \& Koyuncu, 2014):

Güçsüzlük; bireyin, olayların gidişinin kendi istediği gibi gerçekleşmeyeceğine inanması ya da olaylara gerçek benliğini aktaramadığı hissine kapılmasıyla yaşadığı başarısızlık duygusudur.

Anlamsızlık; birinin daha büyük bir amaca olan katkılarını anlayamamaktır.

Kuralsızlık; bireyin amacına ulaşmasını sağlayacak ancak toplum tarafindan onay görmeyen eylemlere başvurmasıdır.

Soyutlanma; bireyin içinde bulunduğu sosyal ve fiziksel çevrede etkileşimde bulunmaktan kaçınmasını ifade eder. 
Öz yabancılaşma; bireyin kendine yabancılaşması ve öz benliğine soğuması olarak tanımlanabilir.

Kendine ve çevresine yabancılaşan bireyin içinde bulunduğu her türlü sosyal ortama da yabancılaşması kaçınılmaz bir durumdur. Çalışan birey açısından işe yabancılaşmadan bahsedilebilir. İşe yabancılaşma; bireyin üretim süreci, ürün üzerindeki kontrolünü ve işte kendini ifade etme kapasitesini kaybetmesiyle ortaya çıar (Mendoza \& Lara, 2007). İşe yabancılaşmanın hem de psikolojik ve hem de sosyal açıdan çalışma ortamını etkileyecek olumsuz sonuçlara neden olmaktadır.

Yabancılaşma konusunda, mesleki yabancılaşma (Şimşek vd., 2012), işe yabancılaşma düzeyi ve örgütsel adalet algısı (Kasapoğlu, 2015), işe yabancılaşma (Celep, 2008), örgütsel sinizm tutumu ve işe yabancılaşma (Anaş, 2016), alkol problemi ve işe yabancılaştırma (Greenberg \& Grunberg, 1995), örgütsel adaletsizlik ve örgütsel bağlılık arasında yabancılaşmanın aracı rolü (Sulu, vd., 2010), iyi oluş ve işe yabancılaşma (Coburn, 1979), yabancılaşma (Chiaburu vd., 2014), algılanan rol belirsizliği ve işe yabancılaşma (Elmas Atay \& Gerçek, 2017), işe yabancılaşma ve örgütsel adalet (Turgut \& Kalafatoğlu, 2016) ile ilgili araştırmalar yapılmıştır.

Yabancılaşma; işe devamsızlık (Turan \& Parsak, 2011), işten ayrılma niyetinde (Celep, 2008; Chiaburu vd., 2014) artış yaratmaktadır. Ayrıca Chiaburu ve arkadaşları (2014) yabancılaşmanın iş memnuniyeti ve örgütsel bağlılık tutumlarını olumsuz yönde etkilediğini, verimliliği düşürdüğünü, tükenmişlik, stres, hastalık ve öfkeye neden olduğunu ifade etmişlerdir. Anaş (2016) sinizim artıkça yabancılaşmanın da artığını bulmuştur. Greenberg \& Grunberg, (1995) işe yabancılaşmanın alkol tüketimini arttırdığını belirlemişlerdir. Hodson \& Sullivan (2011) ise çalışanların sabotaj eğilimlerinde artış olduğunu ifade etmişlerdir (akt. Turgut \& Kalafatoğlu, 2016). Yoğun bir şekilde duygusal emek harcanan örgütlerde çalışanların işe yabancılaşma düzeylerinde artış olduğunu belirlemişlerdir (Sulu vd., 2010; Kökden, 2018). Coburn (1979), bireylerin işe yabancılaşma düzeyleri ile iyi oluş halleri arasında negatif yönlü bir ilişki olduğunu belirtmektedir. Mendoza \& Lara (2007), yabancılaşmanın birey-örgüt uyumu ve örgütsel vatandaşlık davranışı arasında düzenleyici rolü olduğu bulmuşlardır. Rol belirsizliğinin işe yabancılaşmayı artırdığı (Elmas Atay \& Gerçek, 2017), işe yabancılaşma ile örgütsel adalet arasında ters yönlü bir ilişki olduğu (Turgut \& Kalafatoğlu, 2016) görülmüştür.

Demografik değişkenlerle yabancılaşma arasındaki ilişki incelenecek olursa; yabancılaşma ile ilgili Kuzey Avusturalya'da lise öğrencileri üzerinde yapılan bir araştırmaya göre cinsiyetin yabancılaşma seviyesinin değiştirmediği ancak başarısız öğrencilerin başarılı öğrencilere karşı öfke ve kıskançlık duyduğu tespit edilmiştir (Trend, 2001; akt. Avcı, 2012). Şimşek (2002) öğretmenler üzerinde yapmış olduğu araştırmada mezun olunan bölüm ve görev yapılan okulun eğitim imkanlarının yeterlik derecesinin mesleki yabancılaşmaya neden olduğunu belirtmiştir. Kasapoğlu (2015) ise işe yabancılaşmanın yaş ve kıdemle ilişkili olduğunu bulmuştur. Kıdemin işe yabancılaşma üzerinde farklılık yarattığı belirlenmiştir (Elmas Atay \& Gerçek, 2017).

Özellikle hizmet sektöründe ve insanlarla sürekli etkileşim halinde olan iş yerlerinde yabancılaşmanın etkilerinin görülmesi kaçınılmaz olacaktır. Yabancılaşmanın çalışanların işten ayrılma niyeti, iş tatmini, işe devamsızlık ve tükenmişlik duyguları üzerinde etkisi bulunmaktadır.

Örgütün hedeflerine ulaşması çalışanların bu hedefleri ne kadar benimsediği ile yakından ilgilidir. Belirlenen hedefler doğrultusunda çalışanların işe yabancılaşması önlenmeli kendilerine verilen önem ve değer örgüt tarafindan hissettirilmelidir. 


\section{2.Üretim Karşıtı İş Davranışları}

Beklenmeyen davranışlar, sapkın davranışlar ve üretkenlik karşıtı iş yeri davranışları şeklinde de ele alınmaktadır. Sapma kavramı, örgütü veya örgüt çalışanlarını ya da örgütün refahını etkileyebilecek gönüllü davranışlar olarak tanımlanmaktadır (Kaplan, 1975; akt. Robinson \& Bennett, 1995). Bir başka ifadeyle sapkın davranışlar örgüte, örgüt çalışanlarına veya her ikisine birlikte aynı anda zarar verme potansiyeli bulunulan davranışlar şeklinde tanımlamaktadır (Cohen, 1966; akt. Robinson \& Bennett, 1995). İşyerinde yıkıcı iş davranışları, "çalışanların organizasyona zarar verici ve organizasyonun işleyişini bozma niyetiyle gerçekleştirdiği kasıtlı davranışlar" olarak tanımlanmaktadır (Marcus \& Schuler, 2004; Demir \& Tütüncü, 2010). Vardi ve Wiener (1996)'e göre ise, "örgütün normlarına ve beklentilerine veya paylaşılan ortak değerlerine karşı, zarar verici kasıtlı eylemler" olarak tanımlanmaktadır. Üretim karşıtı iş davranışları, hırsızlık, işyerindeki mala zarar verme, kaynakların kötüye kullanılması, işe devamsızlık, işi yavaşlatma, agresif davranışlar şeklinde kendini göstermektedir (Furnham \& Taylor, 2004; Seçer \& Seçer, 2009). Öcel (2010), üretim karşıtı iş davranışlarını kötüye kullanma, çalma, geri çekilme ve sabotaj olarak dört boyutta incelenmektedir.

Çalışanlar, örgütün sosyo-psikolojik beklentilerinin karşılanmaması durumunda yaşadıkları kırgınlık ve kızgınlık gibi olumsuz duyguların yaşanmasıyla üretim karşıtı iş davranışlarında bulunulabilmektedir (Doğan \& Deniz, 2017). Bu durumun sonucu olarak çalışanlar, iş pozisyonlarına göre, protesto edilecek hedef belirleyip memnuniyetsizlik belirtisi olarak üretim karşıtı iş davranışlarında bulunabilmektedirler (Özüren, 2017). Martinko vd. (2002) ise cinsiyet, kontrol odağ (locus of control), atfetme biçimi, kendi kendine yetme durumu, bütünleşme ve psikolojik durumun üretim karşııı iş davranışlarına etki eden unsurlar olarak belirtmişlerdir (akt. Furnham \& Taylor, 2004). Bu unsurlara ilave işin niteliği (Vardi \& Wiener, 1996), örgütsel yap1, örgütsel iklim (Seçer \& Seçer, 2009), örgütsel adalet (Demir vd., 2018), psikolojik antlaşma (İyigün \& Çetin, 2012; Özdemir \& Demircioğlu, 2015) gibi faktörlerin de üretim karşıtı iş davranışlarını etkilediği belirtilmektedir. Bu çalışmalardan yola çıkarak üretim karşıtı iş davranışlarının, kişisel özelliklerin yanı sıra örgüt özelliklerinin de teşvik edici olmasıyla oluştuğunu (Seçer \& Seçer, 2009) ifade etmek yerinde olmaktadır.

Üretim karşıtı iş davranışlarıyla; örgüte bağlılık (Demirel, 2009), işten ayrılma (Demir \& Tütüncü, 2010), psikolojik sözleşme (İyigün \& Çetin, 2012), etik liderlik, örgütsel adalet (Yesiltaş vd., 2012), psikolojik güçlendirme, adaletsizlik, agresif davranışlar, benlik ve sosyal bütünleşme (Bal Taştan, 2013), yönetim tarzı ve işe yabancılaşma (Kanten ve Ülker, 2014), algılanan örgütsel destek, duyuşsal iyi oluş hali (Akbaş-Tuna, Boylu, 2016), liderlik tarzı (Doğan \& Deniz, 2017), nepotizm (Özüren, 2017), işe yabancılaşma (Uysal, 2018) gibi kavramlarla çalışıldığı görülmektedir. Özüren (2017) nepotizmin üretkenlik karşıtı iş davranışlarıyla pozitif yönlü ilişkisini tespit etmiştir. Polatçı ve Özçalık (2015), adaletin üretim karşıtı iş davranışları arasında negatif yönde etkilediğini bulmuşlardır. Doğan ve Deniz (2017), örgüt kültürünün üretim karşıtı iş davranışlarıyla liderlik tarzı arasındaki doğru yönlü ilişkide düzenleyici rolü olduğunu bulmuşlardır. Demir vd., (2018) örgütsel adaletin üretim karşıtı iş davranışlarını pozitif yönde artırdığını belirtmişlerdir.

Kanten ve Ülker (2014) otokratik yönetim biçimini tercih eden liderlik tarzının üretim karşıtı iş davranışlarına etkisi olmadığını, işe yabancılaşmayı pozitif yönde etkilediğini ve demokratik liderlik tarzının işe yabancılaşma ve üretim karşıtı iş davranışlarıyla ters yönlü bir ilişkide olduğunu bulmuşlardır. Özdemir \& Demircioğlu'nun (2015) araştırma sonucuna göre psikolojik 
sözleşme ihlali üretim karşıııı iş davranışlarına yol açmaktadır. Akbaş-Tuna \& Boylu (2016), örgütsel desteğin üretim karşıtı iş davranışları azaltıcı bir rol oynadığını belirtmişlerdir. Uysal (2018), Zonguldak’ta özel sektör çalışanları üzerinde yapmış olduğu çalışma sonucunda işe yabancılaşmanın üretim karşıtı iş davranışlarını arttırdığını tespit etmiştir.

\section{Araştırmanın Yöntemi}

\subsection{Araştırmanın Amacı, Kapsamı ve Yöntemi}

Yapılan literatür taraması sonucunda, insanların sürekli etkileşim halinde oldukları hizmet sektörü, sağlık sektörü gibi sektörlerde işe yabancılaşma durumu ile karşılaşılacağı; işe yabancılaşmanın üretim karşıı iş davranışlarına neden olabileceği düşünülmektedir. Literatür taramasında her iki kavramın birlikte ele alınarak sağlık çalışanları üzerinde pek incelenmediği görülmüştür. Yabancılaşma ile üretim karşıtı iş davranışlarının incelenmesi ve bu ilişkiyi yönlendiren değişkenlerin tespit edilmesi amaçlanarak nicel araştırma kurgulanmıştır. Bu araştırmanın literatüre ve konuyla ilgili araştırma yapanlara yol gösterici olacağı düşülmektedir. Araştırma problemi doğrultusunda belirlenen hipotezler aşağıda verilmiş̧ir:

$\mathrm{H}_{1}$ : Yabancılaşma ile üretkenlik karşıtı iş davranışları arasında anlamlı bir ilişki vardır.

$\mathrm{H}_{1 \mathrm{a}}$ : Güçsüzleşme alt boyutunun üretim karşıtı iş davranışı üzerinde anlamlı bir etkisi vardır.

$\mathrm{H}_{1 b}$ : Sosyal izolasyon alt boyutunun üretim karşıtı iş davranışı üzerinde anlamlı bir etkisi vardır.

$\mathrm{H}_{1 \mathrm{c}}$ : Kuralsızlık alt boyutunun üretim karşıtı iş davranışı üzerinde anlamlı bir etkisi vardır.

$\mathrm{H}_{2}$ : Demografik değişkenler yabancılaşma üzerinde farklılık yaratmaktadır.

$\mathrm{H}_{3}$ : Demografik değişkenler üretim karşııtı iş davranışı üzerinde farklılık yaratmaktadır.

\subsection{Araştırmanın Evreni, Örneklemi ve Ölçekleri}

Araştırma evrenini, Kocaeli İli İzmit İlçesinde hizmet vermekte olan devlet hastaneleri çalışanları oluşturmaktadır. Araştırmaya kolayda örneklem metoduna uygun olarak gönüllü katılan çalışanlar dahil edilmiştir. Örneklem 185 çalışandan oluşmaktadır. Literatürde, faktörlerin güçlü ve belirgin bir yapısı olduğunda eğer değişken sayısı çok büyük değilse örneklem büyüklüğü 100 ile 200 olarak kabul görebilmektedir (Büyüköztürk, 2002).Üretim karşıtı iş davranışları, yabancılaşma ölçeklerinin kullanıldığı ankette, cinsiyet, medeni durum, gelir, eğitim düzeyi gibi dört adet demografik soru bulunmaktadır. Anketler Ocak-Şubat 2019 tarihleri arasında uygulanmıştır. Sağlık çalışanları üzerinde yapılan araştırma mesai saatleri içerisinde gerçekleştirildiğinden zaman; yeterli maddi kaynaklara sahip olunmadığından tek bir ilçe ile sınırlı kalması maliyet ve anketlere katılımın gönüllülük esasına dayalı olması da araştırmanın diğer bir kısıtını oluşturmaktadır.

Üretim karşıtı iş davranışları ölçeği: Ölçeğin orijinali Spector vd. (2006) tarafindan geliştirilmiş olup, ölçeğin Türkçe’ye uyarlaması Öcel (2010) tarafından yapılmıştır. 32 maddeden oluşan ölçek dört boyutludur. Yabancılaşma ölçeği: Ölçeğin orijinali Dean (1961) tarafından geliştirilmiştir. Ölçeğin Türkçe'ye uyarlaması Güğerçin ve Aksay (2017) tarafından gerçekleştirilmiştir. 20 maddeden oluşan ölçek üç boyutludur. Ölçekler 5'li likert tipinde hazırlanmıştır ve "1" Hiç katılmıyorum, "2" Katılmıyorum, "3" Kararsızım, "4" Katılıyorum ve "5” Tamamen katılıyorum ifadelerinden oluşmaktadır. Ölçek soruları EK.1’de gösterilmiştir. 


\section{3.Ölçeklerin Geçerlik ve Güvenirlik Analizleri}

Veriler SPSS 21 programı ile analiz edilmiştir. Analizlerde kullanılan anlamlılık derecesi 0,05 olarak kabul edilmiştir. Verilerin analize uygun olup olmadığına ilişkin yapılan faktör analizi sonuçları aşağıdaki tabloda verilmiştir:

Tablo 1: Faktör Analizi KMO ve Barlett Testi

\begin{tabular}{cccc}
\hline \multicolumn{2}{c}{ Üretim Karşıtı İs Davranışları } & \multicolumn{2}{c}{ Yabancılaşma } \\
\hline KMO &, 950 & KMO &, 873 \\
\hline Barlett Testi Sd & 190 & Barlett Testi Sd & 91 \\
\hline $\mathrm{p}$ &, 00 & $\mathrm{p}$ &, 00 \\
\hline
\end{tabular}

Ölçeklere ilişkin KMO ve p değerinin istenilen limitlerde olduğu görülmüştür. Örneklem büyüklüğünün yeterli olduğuna karar verilmiştir. Bartlett test sonucunun (sırasıyla 1469,67 p< 0,001 ve 1063,43 p<0,001) anlamlı olduğu görülmüştür.

Üretim karşıtı iş davranışları ölçeği dört faktörlü bir yapıya sahip olmasına rağmen hiçbir kısıtlamaya tabi tutulmadan tek faktöre dağılmıştır. Yabancılaşma ölçeği ise üç faktörlü bir yapıya sahiptir ve açıkladığı varyans oranı 49,374'tür. Yabancılaşma ölçeği faktör analizine sokulduktan sonra madde 5 , madde 12 , madde 15 ve madde 17 'nin faktör yükü 0,50 'in altında kaldığı için, madde 8 ile madde 9 iki boyuta dağıldığı için analizden çıkarılmıştır. Üretim karşıtı iş davranışları ölçeğinin analizine 32, yabancılaşma ölçeğinin analizine 14 soru ile devam edilmiştir. Tablo 1'de tekrarlanan faktör analizi sonuçları gösterilmektedir.

Tek faktöre dağılan üretim karşııtı iş davranışları ölçeğinin en yüksek faktör yük değeri .992, en düşük faktör yük değeri .855 'tir. Yabancılaşma ölçeği ise üç faktöre dağılmıştır. Sosyal izolasyon alt boyutunun en yüksek faktör yük değeri .764, en düşük faktör yük değeri .646, güçsüzlük alt boyutunun en yüksek faktör yük değeri .848, en düşük faktör yük değeri .725 , kuralsızlık alt boyutunun en yüksek faktör yük değeri .803, en düşük faktör yük değeri .694'dir. Ölçeklerin özdeğer ve açıkladığı varyans oranları aşağıdaki tabloda gösterilmiştir.

Tablo 2: Ölçeklere İlişkin Varyans Oranları

\begin{tabular}{llllll}
\hline & $\begin{array}{l}\text { Üretim } \\
\text { karşıtı iş } \\
\text { davranışları }\end{array}$ & Yabancılaşma & $\begin{array}{l}\text { Sosyal } \\
\text { izolasyon }\end{array}$ & Güssüzlük & Kuralsızlık \\
\hline $\begin{array}{l}\text { Açıklanan } \\
\text { varyans (\%) }\end{array}$ & 94,762 & 60,439 & 25,907 & 24,380 & 10,153 \\
\hline $\begin{array}{l}\text { Özdeğer } \\
\text { (Eigenvalue) }\end{array}$ & 30,324 & & 5,547 & 1,826 & 1,088 \\
\hline
\end{tabular}


Analizler sonucunda, üretim karşıtı iş davranışları ölçeğinin özdeğeri 1'in üzerinde olan bir faktörden oluşan ve toplam varyansın \% 94,762'sini açıklayan bir yapısının olduğu görülmüştür. Tekrarlanan faktör analizi sonucuna göre yabancılaşma ölçeğinin özdeğeri 1' in üzerinde üç faktörlü bir yapısının olduğu ve toplam varyansın \% 60,439'unu açıklayan bir yapıya dönüştüğü görülmektedir. Bu değerler ölçeklerin açıkladığı varyans oranları kabul edilebilir düzeyde olduğunu göstermektedir. Tekrarlanan faktör analizinden sonra güvenirlik analizi yapılmıştır.

Tablo 3: Ölçek Güvenirlik Katsayıları

\begin{tabular}{ccc}
\hline Faktör & $\begin{array}{c}\text { Orijinal Cronbach } \\
\text { Alfa }\end{array}$ & Güvenirlik Cronbach Alfa \\
\hline Üretim karşıtı iş davranışları & 0,97 & 0,99 \\
\hline Yabancılaşma & 0,88 & 0,86 \\
\hline Sosyal izolasyon & 0,88 & 0,83 \\
\hline Güçsüzlük & 0,86 & 0,85 \\
\hline Kuralsızlık & 0,84 & 0,81 \\
\hline
\end{tabular}

Ölçeklere ilişkin güvenirlik katsayıları Tablo 3'te gösterilmiştir. Ölçeklere ve alt boyutlara ilişkin güvenirlik katsayıları ölçeklerin yüksek güvenilirlikte olduğunu göstermektedir.

Tablo 4: Ölçeklerin Korelasyon Değerleri

\begin{tabular}{|c|c|c|c|c|c|}
\hline Değişkenler & $\begin{array}{c}\text { Üretim Karşıtı } \\
\text { İş } \\
\text { Davranışları } \\
\text { (ÜKİD) }\end{array}$ & $\begin{array}{c}\text { Yabancılaşma } \\
\text { (YAB) }\end{array}$ & $\begin{array}{c}\text { Sosyal } \\
\text { izolasyon } \\
\text { (YSI) }\end{array}$ & $\begin{array}{c}\text { Güçsüzlük } \\
\text { (YG) }\end{array}$ & $\begin{array}{c}\text { Kuralsızlık } \\
\text { (YK) }\end{array}$ \\
\hline ÜKİD & 1 &, $24 * *$ &, $33 * *$ &, 05 &, $19 *$ \\
\hline YAB & & 1 &, $87 * *$ &, $62 * *$ &, $86 * *$ \\
\hline YSİ & & & 1 &, $25 * *$ &, $61 * *$ \\
\hline YG & & & & 1 &, $48 * *$ \\
\hline YK & & & & & 1 \\
\hline
\end{tabular}

Üretim karşıtı iş davranışları ile yabancılaşma $(r=, 24, p<0,01)$ arasında doğru ve düşük, sosyal izolasyon alt boyutu ile $(r=, 33 \mathrm{p}<0,01)$ doğru ve düşük, kuralsızlık alt boyutu ile $(r=, 19, p<0,05)$ doğru ve düşük düzeyde bir ilişki olduğu görülmektedir. Üretim karşıtı iş davranışları ile güçsüzlük alt boyutu arasında bir ilişki olmadığı görülmüştür. Ayrıca yabancılaşma ölçeği ile sosyal izolasyon alt boyutu $(r=, 87, p<0,01)$, güçsüzlük alt boyutu $(r=, 62, p<0,01)$ arasında yüksek düzeyde ve doğru, kuralsızlık alt boyutu $(r=, 86, p<0,01)$ ile yüksek ve doğru yönde bir ilişki olduğu görülmektedir. 


\subsection{Bulgular}

Demografik değişkenlerin normal dağılım gösterip göstermediğine ilişkin göstergeler aşağıdaki tabloda verilmiştir:

Tablo 5: Demografik Değişkenlerin Tanımlayıcı Bilgileri

\begin{tabular}{lccl}
\hline & $N$ & Ort. & Std.Sapma \\
\hline Cinsiyet & 185 & 1,48 & 0,50 \\
\hline Gelir & 185 & 2,77 & 0,73 \\
\hline Medeni durum & 185 & 1,42 & 0,49 \\
\hline Eğitim durumu & 185 & 2,25 & 0,94 \\
\hline
\end{tabular}

Yapılan normallik testi sonucunda Kolmogorov-smirnov testi $\mathrm{p}$ değeri $=0,00$ olduğundan araştırmada kullanılan veriler normal dağılım gösterdiği kabul edilmiştir (Yaşar, 2014: 66). Analizler SPSS 21 programı kullanılarak yapılmıştır. Normal dağılım gösteren verilere parametrik testler uygulanmıştır. Değişkenlerle ilgili analizlerde t-testi, manova, regresyon analizi kullanılmıştır. Demografik değişkenlere ilişkin bilgiler Tablo 6' da sunulmuştur.

Tablo 6: Demografik Değişkenler

\begin{tabular}{llllll}
\hline Değişkenler & $\mathbf{N}$ & $\mathbf{\%}$ & Değişkenler & $\mathbf{N}$ & $\%$ \\
\hline Cinsiyet & & & Medeni durum & & \\
\hline Erkek & 96 & $\% 51,9$ & Evli & 107 & $\% 57,8$ \\
\hline Kadın & 89 & $\% 48,1$ & Bekar & 78 & $\% 42,2$ \\
\hline Gelir düzeyi & & & Eğitim durumu & & \\
\hline 2.999 TL'den az & 75 & $\% 40,5$ & Lise & 45 & $\%$ 24,3 \\
\hline 3.000 - 4.499TL & 77 & $\% 41,6$ & Önlisans & 66 & $\%$ 35,7 \\
\hline 4.500 TL ve üzeri & 33 & $\% 17,8$ & Lisans & 55 & $\% 29,7$ \\
\hline & & & Lisansüstü & 19 & $\% 10,3$ \\
\hline
\end{tabular}

Katılımcıların \% 51,9' unu erkek, \% 57,8' ini evli çalışanlar oluşturmaktadır. Katılımcıların gelir düzeyi incelendiğinde \% 41,6’ sının gelirlerinin 3.000-4.499 TL aralığında olduğu, eğitim düzeylerinin \% 35,7’ sini ön lisans mezunlarının oluşturduğu görülmüştür. 
Tablo 7: Cinsiyet ile Yabancılaşma ve Üretim Karşıtı İş Davranışları İlişkisi

\begin{tabular}{|c|c|c|c|c|c|c|}
\hline Boyutlar & Cinsiyet & $\mathbf{N}$ & ss. & $\mathbf{t}$ & $\mathbf{F}$ & $\mathbf{p}$ \\
\hline \multirow[t]{2}{*}{ Yabancılaş̧ma } & Erkek & 96 & 11,80 & ,094 &, 340 & 0,561 \\
\hline & Kadın & 89 & 11,12 & & & \\
\hline \multirow{2}{*}{$\begin{array}{l}\text { Sosyal } \\
\text { izolasyon }\end{array}$} & Erkek & 96 & 6,58 & ,398 & ,021 & 0,884 \\
\hline & Kadın & 89 & 6,54 & & & \\
\hline \multirow[t]{2}{*}{ Güçsüzlük } & Erkek & 96 & 3,68 & ,212 & 3,593 & 0,060 \\
\hline & Kadın & 89 & 3,12 & & & \\
\hline \multirow[t]{2}{*}{ Kuralsızlı } & Erkek & 96 & 4,26 &,- 536 & ,005 & 0,946 \\
\hline & Kadın & 89 & 4,13 & & & \\
\hline \multirow{2}{*}{$\begin{array}{l}\text { Üretim karşıtı } \\
\text { iş } \\
\text { davranışları }\end{array}$} & Erkek & 96 & 51,90 & 1,526 & 4,923 & $\mathbf{0 , 0 2 8}$ \\
\hline & Kadın & 89 & 46,63 & & & \\
\hline
\end{tabular}

Tablo 7 incelendiğinde yapılan t-testi sonucuna göre erkek katılımcılarla kadın katılımcıların üretim karşıtı iş davranışlarında anlamlı bir farklılık olduğu görülmektedir. Erkek (ort.=66,54) katılımcıların üretim karşıtı iş davranışlarının kadın (ort.= 55,48) katılımcılara göre $\mathrm{p}=0,02<0,05$ anlamlılık seviyesinde daha yüksek olduğu görülmüştür.

Tablo 8: Medeni Durum ile Yabancılaşma ve Üretim Karşıtı İş Davranışları İlişkisi

\begin{tabular}{|c|c|c|c|c|c|c|}
\hline Boyutlar & Cinsiyet & $\mathbf{N}$ & ss. & $\mathbf{t}$ & $\mathbf{F}$ & $\mathbf{p}$ \\
\hline \multirow[t]{2}{*}{ Yabancılaşma } & Evli & 107 & 10,790 & $-2,989$ & ,769 & 0,003 \\
\hline & Bekar & 78 & 11,747 & & & \\
\hline \multirow{2}{*}{$\begin{array}{l}\text { Sosyal } \\
\text { izolasyon }\end{array}$} & Evli & 107 & 5,85 & $-3,582$ & 8,365 & ,000 \\
\hline & Bekar & 78 & 6,96 & & & \\
\hline \multirow[t]{2}{*}{ Güçsüzlük } & Evli & 107 & 3,32 &,- 659 &, 215 & ,511 \\
\hline & Bekar & 78 & 3,55 & & & \\
\hline \multirow[t]{2}{*}{ Kuralsızlık } & Evli & 107 & 4,08 & $-2,133$ & ,095 & ,034 \\
\hline & Bekar & 78 & 4,24 & & & \\
\hline \multirow{2}{*}{$\begin{array}{l}\text { Üretim karşıtı } \\
\text { iş } \\
\text { davranışları }\end{array}$} & Evli & 107 & 52,25 & 2,120 & 9,749 & ,035 \\
\hline & Bekar & 78 & 44,60 & & & \\
\hline
\end{tabular}

Tablo 8 incelendiğinde evli $(=67,60)$ çalışanların üretim karşıtı iş davranışlarının bekar (ort. = 52,46 ) çalışanlara göre $\mathrm{p}=0,035<0,05$ anlamlılık seviyesinde daha yüksek olduğu görülmüştür. Medeni durum ile yabancılaşma arasında $\mathrm{p}=0,003<0,05$ anlamlılık görülmektedir. 
Evli çalışanların (ort. $=10,79)$ yabancılaşma düzeylerinin bekar çalışanlara göre (ort. $=11,74)$ daha düşük olduğu, medeni durum ile sosyal izolasyon arasında $\mathrm{p}=0,00<0,05$ anlamlı bir farkl1lık olduğu görülmekte evli çalışanların (ort. =19,07) sosyal izolasyon düzeylerinin bekar çalışanlara göre (ort. $=22,46$ ) daha düşük olduğu belirlenmektedir. Medeni durum ile kuralsızlık arasında $\mathrm{p}=0,034<0,05$ düzeyinde anlamlı bir farklılık görülmektedir. Evli çalışanların (ort. $=13,67$ ) kuralsılık düzeylerinin bekar çalışanlara göre (ort. =15,00) daha düşük olduğu görülmektedir. Evli çalışanlarla bekar çalışanların güçsüzlük düzeyleri arasında anlamlı bir farklılık ( $\mathrm{p}=0,511>0,05)$ görülmemiştir.

Tablo 9: Gelir ile Yabancılaşma ve Üretim Karşıtı İş Davranışları İlişkisi

\begin{tabular}{|c|c|c|c|c|c|}
\hline Boyut & Gelir & $\mathbf{N}$ & SS. & $\mathbf{F}$ & $\mathbf{p}$ \\
\hline & 2.999 TL'den az & 75 & 11,05 & & \\
\hline & $3.000-4.499 \mathrm{TL}$ & 77 & 11,94 & & \\
\hline \multirow[t]{3}{*}{ Yabancılaşma } & 4.500 TL ve üzeri & 33 & 11,00 & 1,434 & 0,241 \\
\hline & 2.999 TL'den az & 75 & 6,30 & & \\
\hline & $3.000-4.499 \mathrm{TL}$ & 77 & 6,42 & & \\
\hline \multirow[t]{3}{*}{ Sosyal izolasyon } & $4.500 \mathrm{TL}$ ve üzeri & 33 & 7,18 & 2,014 & 0,136 \\
\hline & 2.999 TL'den az & 75 & 3,48 & & \\
\hline & $3.000-4.499 \mathrm{TL}$ & 77 & 3,45 & & \\
\hline \multirow[t]{4}{*}{ Güçsüzlük } & $4.500 \mathrm{TL}$ ve üzeri & 33 & 3,27 & ,028 & 0,973 \\
\hline & 2.999 TL'den az & 75 & 3,85 & & \\
\hline & $3.000-4.499 \mathrm{TL}$ & 77 & 4,57 & & \\
\hline & $4.500 \mathrm{TL}$ ve üzeri & 33 & 3,93 & 1,464 & 0,234 \\
\hline \multirow{2}{*}{ Kuralsızlık } & 2.999 TL'den az & 75 & 49,18 & & \\
\hline & $3.000-4.499 \mathrm{TL}$ & 77 & 45,70 & & \\
\hline $\begin{array}{l}\text { Üretim karşıtı iş } \\
\text { davranışları }\end{array}$ & $4.500 \mathrm{TL}$ ve üzeri & 33 & 43,93 & 1,205 & 0,302 \\
\hline
\end{tabular}

Tablo 9 incelendiğinde çalışanların gelirleri ile yabancılaşma ve yabancılaşmanın alt boyutları olan sosyal izolasyon, güçsüzlük, kuralsızlık ile üretim karşıtı iş davranışları arasında (p değeri $>0,05$ ) anlamlı bir farklılık görülmemiştir. 
Tablo 10: Eğitim ile Yabancılaşma ve Üretim Karşıtı İş Davranışları İlişkisi

\begin{tabular}{|c|c|c|c|c|c|}
\hline Boyut & Gelir & $\mathbf{N}$ & ss. & $\mathbf{F}$ & $\mathbf{p}$ \\
\hline \multirow{4}{*}{ Yabancılaşma } & Lise & 45 & 12,67 & \multirow{4}{*}{0,262} & \multirow{4}{*}{0,853} \\
\hline & Önlisans & 66 & 11,29 & & \\
\hline & Lisans & 55 & 10,87 & & \\
\hline & Lisansüstü & 19 & 11,24 & & \\
\hline \multirow{4}{*}{ Sosyal izolasyon } & Lise & 45 & 6,83 & \multirow{4}{*}{0,185} & \multirow{4}{*}{0,907} \\
\hline & Önlisans & 66 & 6,65 & & \\
\hline & Lisans & 55 & 6,52 & & \\
\hline & Lisansüstü & 19 & 5,94 & & \\
\hline \multirow{4}{*}{ Güçsüzlük } & Lise & 45 & 3,68 & \multirow{4}{*}{0,429} & \multirow{4}{*}{0,732} \\
\hline & Önlisans & 66 & 3,15 & & \\
\hline & Lisans & 55 & 3,50 & & \\
\hline & Lisansüstü & 19 & 3,54 & & \\
\hline \multirow[b]{4}{*}{ Kuralsızlık } & Lise & 45 & 4,11 & \multirow{4}{*}{0,154} & \multirow{4}{*}{0,927} \\
\hline & Önlisans & 66 & 4,20 & & \\
\hline & Lisans & 55 & 4,21 & & \\
\hline & Lisansüstü & 19 & 4,54 & & \\
\hline \multirow{4}{*}{$\begin{array}{l}\text { Üretim karşıtı iş } \\
\text { davranışları }\end{array}$} & Lise & 45 & 48,56 & \multirow{4}{*}{0,687} & \multirow{4}{*}{0,561} \\
\hline & Önlisans & 66 & 44,86 & & \\
\hline & Lisans & 55 & 48,60 & & \\
\hline & Lisansüstü & 19 & 46,00 & & \\
\hline
\end{tabular}

Tablo 10' da çalışanların eğitim düzeyleri ile üretim karşıtı iş davranışları ve yabancılaşma düzeylerine ilişkin analiz sonuçları verilmiştir. Analiz sonucunda elde edilen $p$ değeri $>0,05$ olduğundan ilgili değişkenler arasında anlamlı bir ilişki saptanamamıştır. 
Tablo 11: Yabancılaşma ve Alt Boyutları ile Üretim Karşıtı İş Davranışları İlişkisi

\begin{tabular}{llllllll}
\cline { 2 - 7 } & $\mathbf{R}$ & $\mathbf{R}^{\mathbf{2}}$ & $\mathbf{B}$ & $\boldsymbol{\beta}$ & $\mathbf{T}$ & $\mathbf{F}$ & $\mathbf{p}$ \\
\hline $\begin{array}{l}\text { Bağımsız } \\
\text { değiş̧en }\end{array}$ & & & & & & & \\
\hline Yabancılaşma & 0,248 & 0,062 & 1,016 & 0,248 & 3,465 & 12,008 & $\mathbf{0 , 0 0 1}$ \\
\hline Sosyal izolasyon & 0,336 & 0,113 & 2,405 & 0,336 & 4,823 & 23,263 & $\mathbf{0 , 0 0}$ \\
\hline Güçsüzlük & 0,056 & 0,003 & 0,773 & 0,056 & 0,763 & 0,582 & 0,446 \\
\hline Kuralsızlık & 0,199 & 0,040 & 2,223 & 0,199 & 2,744 & 7,532 & $\mathbf{0 , 0 0 7}$ \\
\hline
\end{tabular}

Bağımlı değişken "üretim karşıtı iş davranışları" p<0,05

Yapılan regresyon analizi sonucunda, yabancılaşmanın, sosyal izolasyonun ve kuralsızlı̆ı̆ın (p değeri $<0,05)$ üretim karşıtı iş davranışlarına etki ettiği görülmektedir. Yabancılaşmadaki bir birimlik artış üretim karşıtı iş davranışları üzerinde 0,248 oranında, sosyal izolasyon üzerindeki bir birimlik artış üretim karşııı iş davranışları üzerinde 0,336 oranında, kuralsızlık üzerindeki bir birimlik artış üretim karşıtı iş davranışları üzerinde 0,199 oranında artışa neden olmaktadır. Güçsüzlüğün üretim karşıtı iş davranışlarına etki etmediği (p değeri > 0,05) görülmektedir.

\section{Sonuç ve Öneriler}

Sağlık, turizm, bankacıllk gibi hizmetlerin sunulduğu sektörler insanların sürekli etkileşim halinde oldukları bir sektörlere örnek verilebilir. Sağlı sektöründe de, hastalık, tedavi süreçleri gibi bazen tahammülü zor durumlarla karşılaşılması strese, tükenmişliğe neden olabilirken yabancılaşma (Erkılıç, 2012) ve üretim karşıtı iş davranışlarını (Demirel \& Seçkin, 2009) tetikleyebilir.

Araştırmada, kadın katılımcıların üretim karşıtı iş davranışlarının erkek katılımcılara göre daha düşük olduğu bulunmuştur. Cinsiyet ile üretim karşıtı iş davranışları arasında benzer bir sonuç da Sezici (2015) tarafından tespit edilmiştir. Yabancılaşma ile cinsiyet arasında bir ilişki olmadığı tespit edilmiştir. Araştırmada, çalışanların gelir ve eğitim düzeyleri ile yabancılaşmanın ve alt boyutları, üretim karşıtı iş davranışları arasında bir ilişki olmadığı görülmüştür. Turan \& Parsak (2011), yaptıkları araştırmada yabancılaşma ile cinsiyet, eğitim arasında bir ilişki bulamamış, gelir ile yabancılaşma arasında anlamlı bir ilişki tespit etmişlerdir. Salihoğlu (2014), yapmış olduğu araştırmada çalışanların cinsiyetleri ve medeni durumlarına göre yabancılaşma arasında bir ilişki olmadığını bulmuştur. Bu araştırmada ise Salihoğlu (2014)'nun tam tersine yabancılaşma ile medeni durum arasında anlamlı farklılık tespit edilmiştir. Evli çalışanların yabancılaşma, sosyal izolasyon, kuralsızlık düzeylerinin bekar çalışanlardan daha düşük olduğu tam tersine evli çalışanların üretim karşıtı iş davranışlarının bekar çalışanlara göre daha yüksek olduğu görülmüştür. Medeni durum ile işe yabancılaşma arasındaki bulgular Ertekin \& Özmen (2017)'nin bulgularıyla örtüşmektedir. Ailenin toplumun en küçük sosyal yapı birimi olduğu düşünüldüğünde evli bireylerin eşleriyle birlikte aynı evi paylaştıklarından yabancılaşma düzeylerinin daha düşük olması doğal bir sonuç olarak görülmektedir. 
Üretim karşıtı iş davranışlarından işe devamsızlık, aşırı mola verme, hırsızlık yapma gibi eylemlerin daha çok evli çalışanlar tarafından gerçekleştirildiği Lau vd. (2003) tarafından bulunmuştur (akt. Seçer \& Seçer, 2009). Bu bulgu çalışmada elde edilen sonucu destekler niteliktedir.

Ayrıca yabancılaşma, sosyal izolasyon, kuralsızlık alt boyutları ile üretim karşıtı iş davranışları arasında doğru yönlü ve düşük düzeyde bir ilişki tespit edilmiştir. Ancak güçsüzlük alt boyutu ile Üretim karşııtı iş davranışları arasında bir ilişki olmadığı görülmüştür. Hipotezlerden $\mathrm{H}_{1}, \mathrm{H}_{1 \mathrm{~b}}$, $\mathrm{H}_{1 \mathrm{c}}$ kabul edilirken, $\mathrm{H}_{1 \mathrm{a}}$ reddedilmiştir. Cinsiyet ve medeni durumun yabancılaşma ve üretim karşıtı iş davranışları üzerinde yarattığı farklılık sonucunda hipotezlerden $\mathrm{H}_{2}$ ve $\mathrm{H}_{3}$ kısmen kabul edilmiştir. sağlık çalışanlarında yabancılaşmanın üretim karşıtı iş davranışlarıyla ilişkili olduğu v bu ilişkinin doğru yönlü olduğu görülmüştür.

Kartal (2017) sağlık çalışanları üzerinde gerçekleştirmiş olduğu çalışmada özel hastane çalışanlarının yabancılaşma düzeylerini en düşük, üniversite ve kamu hastanesi çalışanlarının yabancılaşma düzeylerini orta seviyede bulmuştur. Bu araştırma sadece kamu hastaneleri çalışanları dahil edilmiştir. Ayrıca nicel araştırma değişkenler arasındaki ilişkiyi ortaya koymaktadır. Değişkenler arasındaki ilişkinin nedenini ortaya konması açısından gelecek araştırmalarda nitel yöntem benimsenmesi önerilmektedir. Olumsuz örgütsel davranış konusu içinde değerlendirilebilecek olan üretim karşıtı iş davranışları ve yabancılaşmanın yanı sıra kariyerizm kavramının birlikte çalışılması gelecek araştırmalar için önerilmektedir. Her iki kavramın hastalıklı ya da sorunlu olarak nitelendirilebilecek kişilik özellikleriyle ilişkisi olduğu düşünüldüğünde narsist kişilik yapısını da içine alan araştırmalar da tasarlanabilir.

Literatür incelemesinde de görüldüğü üzere örgüt açısından olumsuz sonuçlar doğuran yabancılaşma ve üretim karşıtı iş davranışlarının önlenmesi için örgütlerde çalışanlara özerklik imkanı verilmelidir. Personel güçlendirme ile özerklik imkanı desteklenmelidir ve dağıtımsal adaletin eşit olduğu bir çalışma ortamı sunulmalıdır. Çalışanlar kariyer imkanlarından eşit olarak faydalandırılmalıdır. Çalışanlara örgütsel destek sağlanmalıdır. Ayrıca liderlik davranışları hizmetkar liderlik, demokratik liderlik tarzına doğru kaydırılmalıdır. Çalışanlar toplum gözünde iyi bir iş yerinde çalıştıklarını düşünerek işe yabancılaşma etkisinden kurtulabilirler. Bu açıdan iyi bir iş yeri markası yaratılmaya çalışılmalıdır.

\section{Kaynakça}

Akbaş-Tuna, A., Boylu, Y. (2016). Algılanan örgütsel destek ve işe ilişkin duyuşsal iyi oluş halinin üretkenlik karşıtı iş davranışları üzerine etkileri: hizmet sektöründe bir araştırma. Ísarder, 8(4), 505-521.

Akyıldız, H., Dulupçu, M. Ali. (2003). Kavramsal ve diyalektik süreç olarak yabancılaşma. Süleyman Demirel Üniversitesi, 8(3), 27-48.

Anaş, K. (2016). Vakıf üniversitesi çalışanlarında örgütsel sinizm tutumunun işe yabancılaşma üzerine etkisi. İstanbul Sabahattin Zaim Üniversitesi Sosyal Bilimler Enstitüsü Yayımlanmamıș Yüksek Lisans Tezi, İstanbul.

Avcı, M. (2012). Eğitimde temel bir sorun: yabanc1laşma. Atatürk Üniversitesi Sosyal Bilimler Enstitüsü Dergisi, 16 (3), 23-40.

Aydoğan, E. (2015). Marx ve öncüllerinde yabancılaşma kavramı. Atatürk Üniversitesi Edebiyat Fakültesi Sosyal Bilimler Dergisi, 54, 273-282. 
Bal Taştan, S. (2013). Bir negatif iş davranışı olarak üretkenliğe aykırı davranışların işyerinde örgütsel adaletsizlik ve agresif davranış algıları ile ilişkisinde psikolojik güçlendirme, benlik değeri ve sosyal bütünleşmenin düzenleyici rolünün incelenmesi: otizm tanısı almış çocuk sahibi çalışanlar üzerine karşılaştırmalı bir araştırma. Sosyal ve Beşeri Bilimler Dergisi, 5(2), 466-481.

Büyüköztürk, Ş. (2002). Faktör analizi: temel kavramlar ve ölçek geliştirmede kullanımı. Kuram ve Uygulamada Eğitim Yönetimi. Güz (32), 470-483.

Celep, B., (2008). İlköğretim ögretmenlerinin işe yabancılaşması (Kocaeli örnĕgi). Kocaeli Üniversitesi Sosyal Bilimler Enstitüsü Yayımlanmamış Yüksek Lisans Tezi, Kocaeli.

Chiaburu, D. S., Thundiyil, T. \& Wang, J. (2014). Alienation and its correlates: a meta-analysis. European Management Journal, 32(1), 24-36.

Coburn, D. (1979). Job alienation and well-being. International Journal of Health Services, 9(1), 41-59.

Dean, D. G. (1961). Alienation: Its meaning and measurement. American Sociological Review, (26)5, 753-758.

Demir, M., Ayas, S. \& Harman, A. (2018). Üretim karşıtı iş davranışları üzerinde örgütsel adalet algısının rolü: banka çalışanları örneği. Javstudies, 4(19), 435-448.

Demir, M., Tütüncü, Ö. (2010). Ağırlama işletmelerinde örgütsel sapma ile işten ayrılma eğilimi arasındaki ilişki. Anatolia: Turizm Araştırmaları Dergisi, 21(1), 64-74.

Demirel, Y. (2009). Örgütsel bağlılık ve üretkenlik karşıtı davranışlar arasındaki ilişkiye kavramsal yaklaşım. İstanbul Ticaret Üniversitesi Sosyal Bilimler Dergisi, (15), 115132.

Demirel, Y., Seçkin, Z. (2009). Tükenmişllik ve üretkenlik karşıtı davranışlar arasındaki ilişkinin kavramsal boyutu. TISK AKADEMI, 2, 145-165.

Doğan, A., Deniz, N. (2017). Algılanan liderlik tarzının üretkenlik karşıtı iş davranışlarının ortaya çıkmasındaki etkisinde örgüt kültürünün rolü. Uluslararası Sosyal Araştırmalar Dergisi, 10(52), 1014-1024.

Elmas Atay, S., Gerçek, M. (2017). Algılanan rol belirsizliğinin işe yabancılaşma üzerindeki etkisinin ve demografik değişkenlere göre farklılıklarının incelenmesi. Ordu Üniversitesi Sosyal Bilimler Araştırmaları Dergisi, 7(2), 321-332.

Erkılıç, E. (2012). Örgütsel stresin örgütsel yabancılaşma üzerine etkisi: beş yıldızlı otel işletmelerinde bir araştırma. Basılmamış Yüksek Lisans Tezi, Afyon Kocatepe Üniversitesi Sosyal Bilimler Enstitüsü, Afyon.

Ertekin, P., Özmen, D. (2017). Bir üniversite hastanesinde çalışan hemşirelerde işe yabancılaşmayı yordayan değişkenlerin incelenmesi. Hemşirelikte Eğitim ve Araştırma Dergisi, 14 (1), 25-30.

Fromm, E. (1996). Sağlıklı Toplum. (Çev.: Y. Salman - Z. Tanrısever). İstanbul: Payel Yayınevi.

Furnham, A., Taylor, J. (2004). The dark side of behaviour at work. The dark side of behaviour at work understanding and avoiding employees leaving, thieving and deceiving. Basingstoke, Hampshire: Palgrave Macmillan Houndmills.

Greenberg, E. S., Grunberg, L. (1995). Work alienation and problem alcohol behavior. Journal of Health and Social Behavior, 36(1), 83-102.

Güğerçin, U., Aksay, B (2017). Dean'in yabancılaşma ölçeğinin Türkçe uyarlaması: geçerlilik ve güvenilirlik analizi. Uluslararası Yönetim İktisat ve Işsletme Dergisi, 13(1), 137-154.

İyigün, N.Ö., Çetin, C. (2012). Psikolojik kontratın örgütsel sapma üzerindeki etkisi ve ilaç sektöründe bir araştırma. Marmara Üniversitesi Sosyal Bilimler Enstitüsü Öneri Dergisi, 10(37), 15-29.

Kanten, P., Ülker, F. (2014). Yönetim tarzının üretkenlik karşıtı iş davranışlarına etkisinde işe yabancılaşmanın aracılık rolü. Muğla Sitkı Koçman Üniversitesi Sosyal Bilimler Enstitüsü Dergisi, 32, 16-40. 
Kartal, N. (2017). Sağlık çalışanlarının işe yabancılaşma düzeylerini ölçmeye yönelik bir araştırma: üniversite, kamu ve özel hastane farklılıkları üzerine bir inceleme. Hacettepe Sağllk İdaresi Dergisi. Gümüşhane Üniversitesi Sosyal Bilimler Enstitüsü Elektronik Dergisi, 8(21), 113-130.

Kasapoğlu, S. (2015). Illköğretim okulu öğretmenlerinin işe yabancllaşma düzeyleri ile örgütsel adalet algıları arasındaki ilişki. Yıldız Teknik Üniversitesi Sosyal Bilimler Enstitüsü, Yayınlanmamış Yüksek Lisans Tezi, İstanbul.

Kökden, F. Ç. (2018). Çalışma hayatında duygusal emek ve işe yabancılaşma ilişkisi: banka çalışanları üzerine bir uygulama. Basılmamış Yüksek Lisans Tezi, Süleyman Demirel Üniversitesi Sosyal Bilimler Enstitüsü, Isparta.

Marcus, B., Schuler, H. (2004). Antecedents of counterproductive behavior at work: a general perspective. American Psychological Association, 89(4), 647-660.

Mendoza, J. S., Lara, P. M. (2007). The impact of work alienation on organizational citizenship behavior in the Canary Islands. International Journal of Organizational Analysis, 15(1), 56-76.

Osmanoğlu, Ö. (2016). Hegel'den Marcuse'ye yabancılaşma olgusu. Üsküdar Üniversitesi Sosyal Bilimler Dergisi, 2(3), 65-92.

Öcel, H. (2010). Üretim Karşıtı iş davranışları ölçeği: Geçerlik ve güvenirlik çalışması. Türk Psikoloji Yazllarl, 13(26), 18-26.

Özdemir, M., Demircioğlu, E (2015). The relationship between counterproductive work behaviours and psychological contracts in public high schools. Cukurova University Faculty Of Education Journal, 44 (1), 41-60

Özüren, Ü. (2017). Tekstil işletmelerinde nepotizm uygulamalarına bağll olarak üretkenlik karşıtı davranışlar ve sonuçları. İstanbul Kültür Üniversitesi Sosyal Bilimler Enstitüsü Basılmamış Yüksek Lisans Tezi, İstanbul.

Polatçı, S., Özçalık, S. (2015). Çalışanların örgütsel adalet algıları ile üretkenlik karşıtı iş davranışları etkileşiminde pozitif ve negatif duygusallığın aracılık etkisi. Dokuz Eylül Üniversitesi Sosyal Bilimler Enstitüsü Dergisi, 17(2), 215-234

Polat, M., Yavaş, T. (2012). Yabancılaşma, kurumsal değerler ve duygu yönetimi denklemi. Ĕ̈itim ve Öğretim Araştırmalarl Dergisi, 1(2), 218-224.

Robinson, S., Bennett, R. J. (1995). A typology of deviant workplace behaviors: a multidimensional scaling study. Academy of Management Journal, 38(2), 555-572.

Salihoğlu, G. H. (2014). Örgütsel yabancılaşma. Organizasyon ve Yönetim Bilimleri Dergisi, $6(2), 1-11$.

Seçer, B., Seçer, H. Ş. (2009). Örgütlerde üretkenlik karşıtı iş davranışları: Belirleyicileri ve önlenmesi. (Ed.) A. Keser, G. Yılmaz, S. Yürür. Çalışma Yaşamında Davranış, 425462. Kocaeli: Umuttepe Yayıncılık.

Sezici, E. (2015). Üretkenlik karşıtı iş davranışları üzerinde kişilik özelliklerinin rolü. Uluslararası İktisadi ve İdari İncelemeler Dergisi, 7(14), 1-22.

Spector, P. E. (2006). Industrial and organizational psychology: Research and practice. NY: Jonh Wiley.

Sulu, S., Ceylan, A. \& Kaynak, R. (2010). Work alienation as a mediator of the relationship between organizational injustice and organizational commitment: implications for healthcare professionals. International Journal of Business and Management, 5(8), $27-$ 38.

Şimşek, H., Ataş Akdemir, Ö. (2015). Üniversite Öğrencilerinde Okula Yabancılaşma. Curr Res Educ, 1(1), 1-12.

Şimşek, H., Balay, R. \& Şimşek, A. S. (2012). İlköğretim sınıf öğretmenlerinde mesleki yabancılaşma. Eğitim Bilimleri Araştırmaları Dergisi, 2(1), 53-72. 
Şimşek, M.Ş., Çelik, A., Akgemci, T. \& Fettahlığlu, T. (2006). Örgütlerde yabancılaşmanın yönetimi araştırması. Selçuk Üniversitesi Sosyal Bilimler Enstitüsü Dergisi, 15, 569587.

Tezcan, M. (1985). Gençlik ve yabancılaşma. Ankara Üniversitesi Eğitim Bilimleri Fakültesi Dergisi, 18(1): 121-127.

Turan, M., Parsak, G. (2011). Yabancılaşma ve iş tatmini ilişkisi: bir devlet üniversitesi idari personeli üzerinde araştırma. Ç. ̈̈. Sosyal Bilimler Enstitüsü Dergisi, 20(2), 1-20.

Turgut, T., Kalafatoğlu, Y. (2016). İşe yabancılaşma ve örgütsel adalet. Işs, gü̧̧ Endüstri Illişkileri ve Insan Kaynakları Dergisi, 18(1), 23-46.

Tutar, H. (2010). İşgören yabancılaşması ve örgütsel sağlık ilişkisi: Bankacılık sektöründe bir uygulama. Ankara Üniversitesi SBF Dergisi, 65(1), 175-204.

Uysal, H. T. (2018). Çalışanlarda işe yabancılaşmanın üretkenlik karşıtı iş davranışlarına etkisi. BMIJ, 6(4), 1434-1454.

Vardi, Y., Wiener, Y. (1996). Misbehavior in organizations: a motivational framework. Organization Science, 7(2): 151-165.

Yalçın, İ., Koyuncu, S.C. (2014). Örgütsel yabancılaşma olgusunun iş tatmini üzerine etkisi: Niğde ilinde bir araştırma. KMÜ Sosyal ve Ekonomik Araştırmalar Dergisi, 16(26): 86-94.

Yaşar, M. (2014). İstatistiğe yönelik tutum ölçeği: geçerlilik ve güvenirlik çalışması. Pamukkale Üniversitesi Ĕ̆itim Fakültesi Dergisi, 36(2014/2), 59-75.

Yesiltaş, M., Çeken, H. \& Sormaz, Ü. (2012). Etik liderlik ve örgütsel adaletin örgütsel sapma davranışları üzerindeki etkisi. Muğla Üniversitesi Sosyal Bilimler Enstitüsü Dergisi, (28), 18-39. 